\title{
ANALISIS DAMPAK TARIF IMPOR TERHADAP PERKEMBANGAN NERACA PERDAGANGAN INDONESIA (Periode 1995.1 - 2005.4)
}

\author{
Nazaruddin Malik \\ Dosen Fakultas Ekonomi Universitas Muhammadiyah Malang \\ Kusuma Wulandari \\ Alumnus Jurusan Ilmu Ekonomi Fakultas Ekonomi Universitas \\ Muhammadiyah Malang
}

\begin{abstract}
Abstraksi
One of the used policy form government to push exporting to be natural balance of trade surplus $(X>M)$ is with imposition of import tariff. This research aim to know tariff impact import to growth of balance of trade in Indonesia [at] period 1995.1-2005.4. By using Linier Model analysis method Dinamik (MLD) through approach of Error Correction Model (ECM), known that import tariff have an effect on positive to growth of balance of trade. Its meaning, if natural tariff of increase hence will give impact go up him growth of balance of trade (surplus) which significant.
\end{abstract}

Keyword:balance of trade, import tariff, surplus 


\section{PENDAHULUAN}

Globalisasi sering dikaitkan dengan adanya perdagangan bebas yang terjadi antar negara. Sifat perekonomian Indonesia yang terbuka mengharuskan untuk diperkuatnya home front agar dapat memperoleh manfaat yang sebesarbesarnya dari peluang yang tercipta di tengah persaingan yang semakin ketat.. Dengan demikian seluruh potensi yang dimiliki harus dapat dieksploitasi secara optimal dan tepat (Basri, 1995)

Tantangan utama bagi Indonesia saat ini adalah bagaimana meningkatkan nilai ekspor sekaligus meningkatkan penerimaan negara (persediaan devisa) dari sektor ekspor. Secara teoritis ekspor tidak sekedar membentuk surplus neraca perdagangan. Keberhasilan peningkatan ekspor merupakan salah satu sumber penting pertumbuhan ekonomi dan pendapatan nasional. Memang seperti dinyatakan Aliman dan Ade (2000), masih terdapat perdebatan soal apakah ekspor menyebabkan pertumbuhan ekonomi (export-led growth) sebagaimana didengungkan Bank Dunia atau sebaliknya pertumbuhan ekonomi yang mendorong ekspor (growth-led export). Namun juga terbuka kemungkinan ekspor mengurangi pertumbuhan ekonomi (export reducing growth) atau pertumbuhan ekonomi berpotensi mengurangi ekspor (growth reducing export) sebagaimana dikatakan Jung dan Marshall (1985).

Salah satu bentuk kebijaksanaan perdagangan yang relatif masih populer adalah kebijakan tariff impor. Jika diterapkan diharapkan dapat meningkatkan penerimaan negara, mendorong ekspor dan melindungi (proteksi) sektor produksi tertentu dari persaingan. Namun sejalan dengan semakin kuatnya arus liberalisasi menuju pasar bebas, kebijakan tarif impor seringkali justru menjadi sebuah paradoks. Tarif dipandang dapat mengurangi manfaat perdagangan atau mereduksi tingkat kesejahteraan dari perdagangan dalam arti luas. Namun realitasnya masih banyak diterapkan baik secara eksplisit maupun terselubung.

Kebijaksanaan perdagangan negara-negara maju yang kerap bersifat ambigu dapat dijadikan contoh. Disatu sisi menggencarkan arus pasar bebas melalui berbagai forum ekonomi dunia yang dikuasainya tetapi disisi lain masih memproteksi secara ketat pasarnya dengan tujuan perlidungan dan efisiensi bagi 
sektor-sektor tertentu di negaranya. Amerika Serikat dan negara-negara Eropa Barat teguh memproteksi sektor pertaniannya diikuti upaya-upaya untuk terus meliberalisasikan sektor manufaktur mereka yang memang sudah mapan dan memiliki efisiensi tinggi. Sebaliknya negara-negara berkembang malah melindungi industri manufaktur mereka dan tak tertarik pada lobi untuk liberalisasi produk pertanian (Bhagwati, 1988:9-10)

Fakta ini didukung buki-bukti terus berlanjutnya upaya liberalisasi pasar. Semenjak diberlakukannya ASEAN Free Trade Area (AFTA) melalui Common Effective Preferential Tariff (CEPT) sebagai wujud dari kesepakatan negaranegara anggota ASEAN untuk membentuk kawasan bebas perdagangan, menunjukkan bahwa pada tahun 2003 sekitar 99,07\% tarif CEPT Indonesia berada antara $0-5 \%$. Kemudian, kesepakatan dalam AFTA selain menurunkan tarif juga menghapuskan hambatan kuantitatif (quantitative restriction) dan hambatan nontarif (non-tarif barriers). Selanjutnya, untuk sebelas sektor prioritas yaitu produk kayu, otomotif, produk karet, tekstil, garmen, produk pertanian, produk perikanan, elektronik, produk kesehatan, transportasi udara dan pariwisata, tarif akan diturunkan hingga nol, hambatan non tarif dihapuskan dan batasan nilai tukar terhadap produk-produk tersebut diharmonisasikan.

Semakin terkaitnya perekonomian Indonesia dalam dunia global menyebabkan kita terikat dengan aturan World Trade Organization (WTO), diantaranya yaitu; (1) Menghilangkan tariff surchange pada tahun 2004; (2) menghilangkan seluruh hambatan non-tarif (NTB / non-tariff barrier) pada tahun 2004; (3) Menjaga tarif yang berlaku dibawah batas maksimum yang ditetapkan dalam komitmen WTO; (4)Mengurangi tarif untuk produk-produk teknologi informasi sampai dengan $0 \%$.

Jadi terdapat kecenderungan yang semakin tidak mudah bagi pemerintah untuk menentukan tarif impor. Karena itu dibutuhkan kebijakan perdagangan internasional yang tepat dan didukung lingkungan makro dan mikro ekonomi yang kondusif agar dapat meningkatkan posisi kompetitif di pasar internasional.

Neraca perdagangan merupakan sumber informasi penting untuk mengetahui kondisi perekonomian suatu negara karena menggambarkan transaksi- 
transaksi (lalu lintas ekspor dan impor barang dan jasa) antara Indonesia dengan negara-negara mitra dagangnya. Informasi neraca perdagangan merupakan input bagi desain kebijakan dan sistem pendukung keputusan strategis berkenaan dengan kegiatan perdagangan internasional.

Makalah ini mencoba menjawab "apakah pengenaan tarif impor masih berpengaruh signifikan terhadap perkembangan neraca perdagangan?".

\section{LANDASAN TEORI DAN PENGEMBANGAN HIPOTESIS}

\section{Tinjauan Empiris}

Basuki (2000), meneliti tentang kebijakan tarif di Indonesia dan kesiapan dalam menghadapi pelaksanaan AFTA pada tahun 2003. Model analisisnya menggunakan ERP (Effektive Rate of Protection) dan DRC (Domestic Resource Cost). ERP merupakan perbandingan ouput industri pada sistem proteksi yang berlaku dibandingkan dengan output yang terjadi pada saat pasar yang dihadapi tidak mengalami hambatan perdagangan (trade barrier). DRC merupakan perluasan dari analisis Ricardo mengenai keunggulan komperatif. Analisa DRC pada dasarnya merupakan indikator untuk melihat apakah produksi suatu barang didasarkan pada keunggulan komparatif yang dimiliki oleh suatu negara atau tidak.

Kesimpulannya, bahwa pada intinya sektor industri masih mendapatkan proteksi besar dari pemerintah, tingkat proteksi efektifnya diatas 5\%.Tidak efisiennya industri merupakan tantangan untuk mengefisienkan proses produksi terutama untuk sektor yang memiliki nilai ERP rata-rata diatas $20 \%$ dan ERP antara 5-20\%. Penurunan tarif nominal pada 66 sektor industri yang diteliti akan membawa dampak besar, karena semua industri memiliki DRC (Domestic Resource Cost) lebih besar dari kurs (tidak memiliki comparative advantage), akibat sektor industri masih mendapatkan proteksi besar dari pemerintah. Upaya penurunan tarif nominal perlu secara teknis diwujudkan dasar daya saing sektor yang diproteksi, sebab penurunan tarif nominal pada sektor tersebut akan membawa dampak besar berupa penghematan devisa dan alokasi sumberdaya yang efisien. 
Kariyasa (2003), difokuskan untuk melihat kinerja kebijakan harga dasar beras selama ini dan kinerja kebijakan harga dasar baru yang ditetapkan pemerintah. Juga dianalisis perkembangan produksi, konsumsi, dan impor beras di Indonesia, dampak kebijakan tarif impor terhadap kesejahteraan masyarakat, dan daya saing komoditas beras Indonesia di pasar dunia.

Metode analisisnya menerapkan Model Kesejahteraan Masyarakat dan Analisis Daya Saing Komoditi. Kesimpulannya, bahwa kebijakan tarif impor telah berdampak terhadap distribusi pendapatan di antara pelaku pasar. Berkurangnya surplus konsumen, meningkatkan surplus produsen, serta adanya kerugian sosial (akibat terjadinya efisiensi produksi dan efisiensi ekonomi) seiring dengan besarnya tingkat tarif yang diberlakukan. Akan tetapi penerimaan pemerintah akan meningkat seiring dengan meningkatnya tarif yang diberlakukan, dan setelah mencapai equilibrium akan mengalami penurunan dan berlawanan arah dengan kenaikan tarif.

Secara umum dapat dilihat, kebijakan tarif impor telah mengurangi kesejahteraan masyarakat. Agar komoditas beras tetap mempunyai daya saing maka efisiensi biaya produksi perlu ditingkatkan sehingga besarnya tarif impor berangsur-angsur bisa dikurangi sampai titik nol, dengan demikian tingkat kesejahteraan masyarakat yang optimal bisa tercapai. Penelitian ini juga mencangkup pembahasan mengenai dampak tarif impor yang dihubungkan dengan kebijakan harga dasar dan kemudian menganalisa pengaruhnya terhadap daya saing beras di pasar dunia.

\section{Landasan Teori}

Ide dasar pengenaan tarif impor berasal dari pendapat kaum Merkantilisme yang mengemukakan bahwa suatu negara akan kaya bila nilai ekspor lebih besar dari pada impor. Walaupun banyak kritik dilontarkan, tetapi pada era globalisasi kebijakan merkantilisme justru masih banyak di praktikkan oleh Negara-negara tertentu dalam bentuk "Neo Merkantilisme", yaitu kebijakan proteksi untuk melindungi dan mendorong ekonomi industri nasional dengan menggunakan kebijakan tarif atau Tariff Barrier (TB) dan kebijakan Nontariff Barrier (NTB). 
Biasanya Tariff Barrier dilaksanakan dengan menggunakan countervailing duty, bea anti dumping, dan surchange. Dalam hal ini, kebijakan proteksi yang lebih banyak digunakan biasanya dalam bentuk Nontariff Barrier (NTB), seperti larangan, sistem kuota, ketentuan teknis, harga patokan (customs value), peraturan kesehatan/karantina, dan lain-lain (Hady,2001: 25). Hal itu juga dilakukan oleh Indonesia dengan tujuan dapat menekan nilai impor sekaligus dapat mendorong ekspor.

Penerapan kebijakan tarif dapat mempengaruhi perekonomian melalui dampaknya terhadap penerimaan ekspor. Pada teori ekonomi makro dikemukakan persamaan identitas berikut:

$Y=C+I+G+(X-$

M)

yaitu bahwa nilai ekspor bersih (X-M) merupakan bagian dari pendapatan nasional (Y), karena akan menginjeksi pendapatan nasional. Pada konsep ekonomi terbuka ekspor dan impor merupakan motor penggerak pertumbuhan ekonomi (engine of growth). Arus ekspor senantiasa diharapkan lebih besar dari impor atau posisi surplus pada neraca perdagangan. Dengan demikian kebijakan tarif impor masih perlu dipertahankan pemerintah untuk menekan impor.

Upaya pemerintah untuk mengembangkan ekspor tersebut dapat diketahui melalui neraca perdagangan yang terdapat dalam neraca pembayaran. Apabila ekspor lebih besar daripada impor $(\mathrm{X}>\mathrm{M})$ maka terdapat selisih bersih positif atau surplus. Demikian juga sebaliknya apabila ekspor lebih kecil daripada impor $(\mathrm{X}<\mathrm{M})$ maka yang terjadi adalah selisih negatif atau defisit. Tarif yang dikenakan pemerintah pada dasarnya diberlakukan untuk mencapai surplus melalui peningkatan nilai ekspor dan pengurangan nilai impor.

\section{Tarif}

Tarif merupakan suatu kebijakan perdagangan yang paling umum adalah sejenis pajak yang dikenakan atas barang-barang yang di impor. Selain itu, tarif 
merupakan bentuk kebijakan perdagangan yang paling tua dan secara tradisional telah digunakan sebagai sumber penerimaan pemerintah (Krugman \& Obsfelt, 1991 : 224). Tarif dapat dikatakan juga sebagai pajak yang dipungut terhadap barang-barang impor pada saat barang tersebut masuk ke suatu negara.

Menurut Tambunan (2004), bahwa di dalam literatur mengenai perdagangan internasional disebut bahwa pengenaan bea masuk (tarif impor) terhadap produk impor mempunyai banyak tujuan, diantaranya melindungi industri atau sector-sektor tertentu di dalam negeri, mengurangi defisit saldo neraca perdagangan, meningkatkan kesempatan kerja, alasan-alasan fiscal, mencegah dumping, dan tujuan politik.

Ada tiga sistem tarif yang umum dikenal di dalam perdagangan internasional, yakni single-column tariff, double-column tariff, dan triple-column tariff. Yang pertama adalah sistem, dimana untuk setiap barang impor dikenakan satu macam tarif. Tarif ini biasanya ditentukan oleh suatu negara secara sepihak (otonom) tanpa persetujuan dari negara mitra dagangnya, oleh karena itu disebut juga autonomous tariff. Jika tingginya tarif ini ditentukan berdasarkan kesepakatan antara suatu negara dengan mitra dagangnya, disebut conventional tarriff (jadi single-column tariff adalah lawan dari conventional tarriff).

Sistem yang kedua, adalah sistem di mana untuk setiap jenis barang dikenakan dua macam tarif yang ditentukan dengan undang-undang dalam bentuk tarif maksimun dan tarif minimum. Bila tarif maksimum dipakai sebagai bea normal (dalam arti dikenakan pada barang impor dari semua negara) yang ditentukan secara sepihak, sedangkan tarif minimum digunakan secara khusus terhadap barang impor dari negara-negara tertentu dengan perjanjian, mala bentuk ini disebut general conventional form, yakni sistem yang sebagian menggunakan autonomous dan sebagian conventional. Sedangkan perluasan dari kedua sistem ini, ditambah dengan satu tarif untuk negara-negara jajahan (preferential system), disebut triple-column tariff.

Tambunan (2004) menyebutkan juga bahwa,tarif dapat dibedakan antara tarif nominal (TN-ad valorem) dan tingkat proteksi efektif atau umum disebut effective rate of protection (ERP). TN adalah besarnya persentase tarif yang 
dikenakan pada sebuah barang tertentu (jadi, setengah jadi atau bahan mentah) yang tercantum di dalam buku tarif BM Indonesia (BTBMI). Misalnya, di dalam BTBMI tercatat bahwa tarif BM terhadap sepatu impor (j) dengan harga $\mathrm{Rp}$ $500.000,00$ adalah $10 \%\left(\mathrm{t}_{\mathrm{j}}\right)$; ini adalah TN yang harus dibayar oleh konsumen di dalam negeri jika membeli sepatu impor tersebut. Pengenaan BM ini bertujuan untuk melindungi industrri sepatu dalam negeri. Pertanyaannya, apakah dengan TN sebesar $10 \%$ itu berarti sepatu nasional secara efektif menikmati perlindungan sebesar $10 \%$ ?

Hal ini tergantung apakah input-output yang diperlukan oleh industri sepatu tersebut harus diimpor atau produksi dalam negeri. Jika input-output tersebut adalah barang impor, pertanyaan berikutnya: apakah input-output tersebut juga dikenakan BM? Contoh, dimisalkan industri sepatu memerlukaan 3 jenis input $(\mathrm{I}=1,2,3)$ yang diimpor, yakni kulit, lem, dan benang dengan besarnya kandungan di dalam nilai impor sepatu $\left(\mathrm{a}_{\mathrm{ij}}\right)$ masing-masing sebagai berikut; $30 \%$, $5 \%$ dan $2 \%$, dan TN $\left(\mathrm{t}_{\mathrm{i}}\right)$ terhadap masing-masing input tersebut sebesar 5\%, 15\%, dan 20\%. Dari uraian ini bisa dihitung nilai tambah dari industri sepatu $\left(\mathrm{NY}_{\mathrm{j}}\right)$ sebelum dikenakan tarif, yakni selisih antara harga barang jadi $\left(\mathrm{P}_{\mathrm{j}}\right)$ dan harga input $\left(\mathrm{P}_{\mathrm{i}}\right)$ :

$\mathrm{NT}_{\mathrm{j}}=\mathrm{P}_{\mathrm{j}}-\mathrm{P}_{\mathrm{i}} ; \mathrm{I}=1,2,3$

Sedangkan nilai tambah dari industri sepatu setelah dikenakan tarif $\left(\mathrm{NT}_{\mathrm{j}}{ }^{*}\right)$ teerhadap impor sepatu $\left(\mathrm{t}_{\mathrm{j}}\right)$ dan ketiga input tersebut $\left(\mathrm{t}_{\mathrm{i}}\right)$ dapat dihitung dengan formula sebagai berikut:

$\mathrm{NTj}^{*}=\mathrm{P}_{\mathrm{j}}\left(1+\mathrm{t}_{\mathrm{j}}\right)-\mathrm{P}_{\mathrm{i}}\left(1+\mathrm{t}_{\mathrm{i}}\right) ; 1,2,3$.

Dari hitungan di atas dapat dilihat bahwa akibat input juga dikenakan tarif (TN), maka NT dari industri sepatu di dalam negeri meningkat, yakni sebesar:

$\mathrm{DNT}_{\mathrm{j}}=\left[\left(\mathrm{NT}_{\mathrm{j}}^{*}-\mathrm{NT}_{\mathrm{j}}\right) / \mathrm{NT}_{\mathrm{j}}\right]$

Atau bisa dihitung dengan rumusan ERP sebagai berikut : 
$\operatorname{ERP}\left(=\mathrm{DNT}_{\mathrm{j}}\right)=\left[\mathrm{t}_{\mathrm{j}}-\mathrm{S}\left(\mathrm{a}_{\mathrm{ij}} \times \mathrm{t}_{\mathrm{j}}\right)\right] /\left(1-\mathrm{S} \mathrm{a}_{\mathrm{ij}}\right)$

Dapat disimpulkan bahwa apabila industri domestik yang dilindungi dari saingan produk impor menggunakan input impor yang dikenai TN yang berbeda daripada tarif TN atas produk akhir, maka TN atas produk akhir tersebut akan berbeda dengan tingkat proteksi efektif atau ERP-nya. Efek proteksi (ERP) terhadap produksi dalam negeri semakin besar apabila tarif BM atas input dipekecil, atau sebaliknya, ERP semakin kecil jika tarif BM terhadap input semakin besar.

Apabila BM juga dikenakan pada input, maka dengan sendirinya biaya produksi di dalam negeri meningkat, sehingga kurva penawaran bergeser ke kiri, dari $S_{0}$ ke $S_{1}$ (gambar 1). Pergeseran kurva itu mencerminkan produksi sepatu menurun pada harga $\mathrm{P}_{0}$ (sebelum BM terhadap sepatu impor) dari titik B ke titik A. Apabila BM juga dikenakan terhadap barang jadi, maka efek dari kenaikan harga ke $\mathrm{P}^{*}$ terhadap peningkatan produksi dalam negeri dilihat dari titik awal $\mathrm{B}$ akan lebih kecil daripada kasus yang mana hanya barang jadi yang dikenakan BM, tetapi tidak terhadap input; keenaikan produksi BD sepanjang kurva $\mathrm{S}_{0}$ lebih besar daripada $\mathrm{BC}$ sepanjang kurva $\mathrm{S}_{1}$. Artinya, bahwa efek proteksi dari $\mathrm{BM}$ atas barang jadi berbeda dengan efek produksi dari BM yang dikenakan terhadap input. Hubungan antara kedua BM tersebut menentukan besar kecilnya ERP.

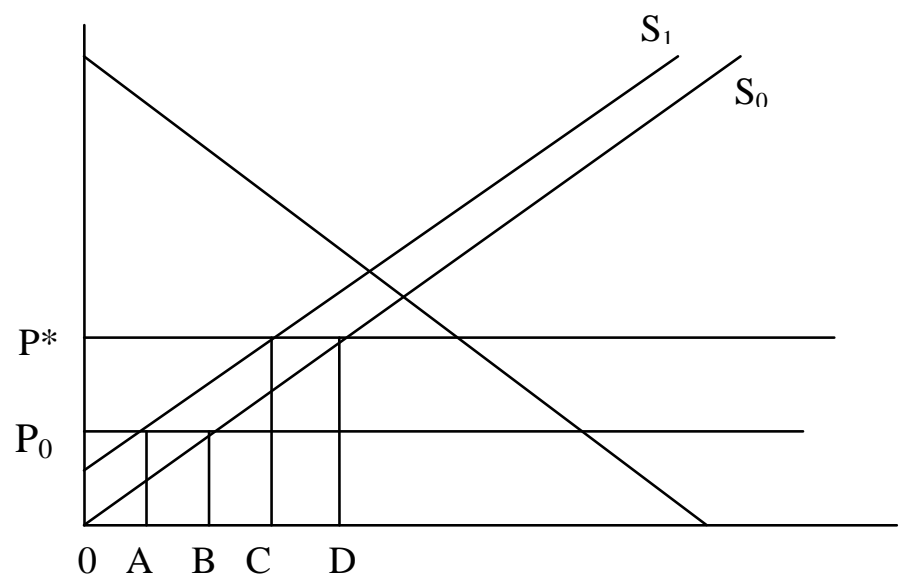

Gambar 1.

Efek Pengenaan BM terhadap Barang Jadi dan Input Sumber: Tambunan (2004 : 354) 


\section{Tarif dan Neraca Perdagangan}

Menurut Mankiw (2003: 217) Dalam perekonomian terbuka, sebagian output dijual untuk domestik dan sebagian diekspor ke luar negeri. Jumlah pengeluaran domestik atas barang dan jasa mancanegara $\left(C^{f}+I^{f}+G^{f}\right)$ adalah pengeluaaran untuk impor $(I M)$. Jadi, dapat dituliskan identitas perhitungan pendapatan nasional di atas menjadi:

$\mathrm{Y}=C+I+G+\mathrm{EX}-\mathrm{IM}$

Karena pengeluaran untuk impor dimasukkan dalam pengeluaran domestik $(\mathrm{C}+\mathrm{I}+\mathrm{G})$, dan karena barang dan jasa yang diimpor dari luar negeri bukanlah bagian dari output suatu negara, maka persamaan ini harus dikurangi dengan pengeluaran untuk impor. Dengan mendefinisikan neraca perdagangan (ekspor neto) sebagai ekspor dikurang impor $(\mathrm{TB}=\mathrm{EX}$ - IM), identitas tersebut menjadi:

$\mathrm{Y}=C+I+G+\mathrm{NX}$

Persamaan itu menyatakan bahwa pengeluaran atas output domestik adalah jumlah dari konsumsi, investasi, belanja pemerintah, dan ekspor neto. Ini adalah bentuk identitas perhitungan pendapatan nasional menunjukkan hubungan antara output domestik, pengeluaran domestik, dan ekspor neto. Dengan demikian, ekspor Neto $=$ Output - Pengeluara domestic, atau

$N X=Y-(C+I+G)$

Pada perekonomian terbuka, pengeluaran domstik tidak perlu sama dengan output barang dan jasa. Jika output melebihi pengeluaran domestik, nilai ekspor neto adalah positif. Jika output lebih kecil dari pengeluaran domestik, nilai ekspor neto adalah negatif. (Mankiw, 2003: 113). Ada tiga hal yang dapat dialami oleh perekonomian negara terbuka pada kondisi neraca perdagangannya (table 1). 
Tabel 3.

Kondisi neraca perdagangan pada perekonomian di negara terbuka

\begin{tabular}{|l|l|l|}
\hline Surplus Perdagangan & Perdagangan Berimbang & Defisit Perdagangan \\
\hline Ekspor $>$ Impor & Ekspor $=$ Impor & Ekspor $<$ Impor \\
Ekspor Neto $>0$ & Ekspor Neto $=0$ & Ekspor Neto $<0$ \\
$Y>C+I+G$ & $Y=C+I+G$ & $Y<C+I+G$ \\
Tabungan $>$ Investasi & Tabungan $=$ Investasi & Tabungan $<$ Investasi \\
Arus Modal Keluar Neto $>0$ & Arus Modal Keluar Neto $=0$ & Arus Modal Keluar Neto $<0$ \\
\hline
\end{tabular}

Sumber: Mankiw (2003 : 220)

Menurut Lindert dan Kindleberger $(1988 ; 4)$ peran pokok tariff terhadap neraca perdagangan tergantung dari elastisitas permintaan yang terkait dengan efek perubahan kurs tukar atas neraca perdagangan. Konsep rumusnya diperoleh dari identitas neraca perdagangan dan diturunkan diferensiasinya menjadi:

$\mathrm{TB}=\mathrm{V}_{\mathrm{x}}-\mathrm{V}_{\mathrm{m}}=\mathrm{P}_{\mathrm{X}} \mathrm{X}-\mathrm{P}_{\mathrm{m}} \mathrm{M}$

Sehingga respon elastisitas neraca perdagangan $\left(\mathrm{E}_{\mathrm{tb}}\right)$ terhadap elastisitas permintaan dan penawaran bagi impor dan ekspor sebagai berikut:

$\left.\mathrm{Etb}=\frac{\mathrm{dTB} / \mathrm{Vm}}{\mathrm{dr} / \mathrm{r}}=\frac{\mathrm{Vx} \mathrm{dx}+1}{\mathrm{Vm} \mathrm{dx} / \mathrm{sx}}\right]-\frac{\mathrm{sm}+1}{(\mathrm{sm} / \mathrm{dm})-1}$

Dimana:

Etb = elastisitas neraca perdagangan terhadap kurs tukar

TB = neraca perdagangan, atau surplus netto atas rekening koran, atau kelebihan netto dari penawaran valuta asing.

$\mathrm{V}_{\mathrm{X}}, \mathrm{V}_{\mathrm{m}}=$ nilai impor dan ekspor sebelum devaluasi atau depresiasi.

$\mathrm{r} \quad=$ kurs tukar, atau harga dari valuta asing

$\mathrm{d}_{\mathrm{x}}, \mathrm{d}_{\mathrm{m}}=$ elastisitas permintaan bagi ekspor dan impor, dirumuskan persentase tanggapan (negatif) dari permintaan ekspor dan impor terhadap prosentase perubahan dalam harga impor dan ekspor masing - masing.

$\mathrm{s}_{\mathrm{X}}, \mathrm{s}_{\mathrm{m}}=$ elastisitas penawaran bagi ekspor dan impor, dirumuskan sebagai presentase tanggapan (positif) dari penawaran ekspor dan impor 
terhadap persentase perubahan dalam harga ekspor dan impor masing masing.

Para pembuat kebijaksanaan dan para pemilik yang hanya berminat terhadap perkiraan kasar mungkin dapat menghindarkan penggunaan rumus ini dan berdasar kepada pola - pola yang diungkapkan oleh kasus - kasus yang terjadi. Namun para ahli ekonomi yang ingin memberikan ukuran kuantitatif khusus mengenai dampak devaluasi atas neraca perdagangan perlu menerapkan perkiraan elastisitas. Apabila asumsi - asumsi mengenai elastisitas khusus dipakai, maka pPenerapan rumus umum kepada kasus - kasus khusus dalam devaluasi dan neraca perdagangan digambarkan pada tabel 2.

Pada kasus 1 dimana $\mathrm{d}_{\mathrm{m}}=\mathrm{d}_{\mathrm{x}}=0$, permintaan elastis terjadi dalam jangka pendek, karena itu elastisitas permintaan belum mempunyai kesempatan untuk meningkat. Kasus 2, merupakan kasus negara kecil, di mana baik harga ekspor maupun harga impor ditetapkan dalam mata uang luar negeri dalam pasar luar negeri yang besar. Kasus ini ditunjukkan dengan elastisitas luar negeri yang tidak terhingga: $s_{m}=-d_{x}=\infty$. Devaluasi atau depresiasi mata uang dalam negeri pasti akan memperbaiki neraca perdagangan, yang membuat pasar valuta asing menjadi stabil kembali. Kasus negara kecil merupakan keadaan yang realistis bagi kebanyakan negara, bahkan banyak negara "besar" yang menjadi penerima harga internasional, sehingga hasilnya yang stabil merupakan alasan utama dari upaya memperbaiki neraca perdagangan yang akan meringankan tugas menstabilkan pasar valuta asing.

Kasus 3. Sebagai contoh, dengan harga - harga yang ditetapkan dalam mata uang para pembeli dan dengan elastisitas permintaan impor yang tak terhingga, baik di dalam negeri maupun diluar negeri $\left(d_{m}=d_{x}=-\infty\right)$, maka akan menghasilkan perbaikan yang terbanyak. Hal ini benar - benar merupakan pengaruh jangka pendek yang realistis bagi kebanyakan barang - barang manufaktur dan jasa-jasa, dimana kesepakatan yang dijanjikan dan hasrat para penjual untuk menghindari terganggunya pasar karena kenaikan harga mengakibatkan harga tidak dipengaruhi oleh perubahan nilai tukar. 
Kasus 4 adalah harga-harga ditetapkan dengan mata uang para penjual. Kasus ini cocok dengan sekumpulan model makro aliran Keynes, dimana berbagai penawaran mempunyai elastisitas yang tak terhingga dan harga - harga ditetapkan di berbagai negara. Dalam kasus ini, efek netto dari devaluasi terhadap neraca perdagangan tergantung pada kondisi Marshall Lerner, yang sangat terkenal, yaitu nilai absolut dari elastisitas permintaan ekspor dan impor harus melebihi datu $\left[d_{x}\right.$ $\left.+d_{m}\right]>1$. Hal ini memenuhi syarat kecukupan untuk mendapatkan hasil yang stabil, apabila neraca perdagangan tidak diawali dengan surplus (yaitu apabila $V_{x}$ $\leq \mathrm{V}_{\mathrm{m}}$, seperti yang biasa terjadi sebelum melakukan devaluasi).

Tabel 2. Devaluasi dan neraca perdagangan

\begin{tabular}{|l|l|l|}
\hline & Asumsi elastisitas & $\begin{array}{l}\text { Dampak devaluasi atas neraca } \\
\text { perdagangan }\end{array}$ \\
\hline Kasus 1 : Permintaan inelastis & $\mathrm{d}_{\mathrm{m}}=\mathrm{d}_{\mathrm{x}}=0$ & $\begin{array}{l}\text { Neraca perdagangan memburuk: } \\
\mathrm{E}_{\mathrm{tb}}=-\mathrm{V}_{\mathrm{x}} / \mathrm{V}_{\mathrm{m}}<0\end{array}$ \\
\hline $\begin{array}{l}\text { Kasus 2: Negara Kecil } \\
\begin{array}{l}\text { Kasus 3: Harga }- \text { harga menetap } \\
\text { dalam mata uang pembeli }\end{array}\end{array}$ & $\mathrm{d}_{\mathrm{m}}=\mathrm{d}_{\mathrm{x}}=-\infty$ & $\begin{array}{l}\text { Neraca perdagangan membaik: } \\
\mathrm{E}_{\mathrm{tb}}=-\frac{V x}{V m} S x-d m>0\end{array}$ \\
\hline $\begin{array}{l}\text { Kasus 4 : Harga }- \text { harga menetap } \\
\text { dalam mata uang penjual }\end{array}$ & $\mathrm{s}_{\mathrm{x}}=\mathrm{s}_{\mathrm{m}}=\infty$ & $\begin{array}{l}\text { Neraca perdagangan membaik: } \\
\mathrm{E}_{\mathrm{tb}}=\frac{V x}{V m} S x+S m+1>0\end{array}$ \\
& $\begin{array}{l}\text { Bergantung } \\
\mathrm{E}_{\mathrm{tb}}=\frac{V x}{V m}(-d x-1)-d m-0\end{array}$ \\
\end{tabular}

Sumber: Kindleberger \& Lindert ( $1988: 4$ )

\section{Kerangka Pemikiran Penelitian Dan Hipotesis}

Gambar 1 menjelaskan tentang hubungan ataupun pengaruh dari tarif impor terhadap perkembangan neraca perdagangan. Dari kebijakan tarif impor yang dikeluarkan oleh pemerintah secara otomatis akan berdampak pada seluruh komoditi impor yang terkena tarif impor. Dari keseluruhan total nilai impor 
tersebut akan mengurangi nilai ekspor. Selisih dari nilai ekspor dengan nilai impor (X-M) akan disebut sebagai neraca perdagangan. Apabila selisih dari nilai ekspor dengan nilai impor menunjukkan angka positif (ekspor lebih besar daripada impor) maka neraca perdagangan dinyatakan surplus. Demikian juga sebaliknya. Apabila selisih ekspor-impor negatif maka neraca perdagangan dinyatakan defisit. Dari selisih nilai ekspor dan impor tersebut akan mempengaruhi besarnya nilai pendapatan nasional. Yaitu akan menambah nilai GNP apabila X-M pada posisi surplus dan akan mengurangi apabila defisit.

Dengan demikian kondisi pendapatan nasional yang diterima, secara tidak langsung dapat dijadikan acuan pemerintah untuk menentukan kebijakan selanjutnya yang berkenaan dengan tarif impor. Dimana dengan melihat pendapatan nasional yang diterima, diharapkan kebijakan tarif yang dikenakan dapat menentukan besarnya pendapatan nasional. Sehingga, kebijakan tersebut dapat memberikan asupan positif untuk perbaikan kondisi ekonomi selanjutnya.

Gambar 1. Kerangka Berpikir Analisis Tarif Impor, Neraca Perdagangan Dan Pendapatan

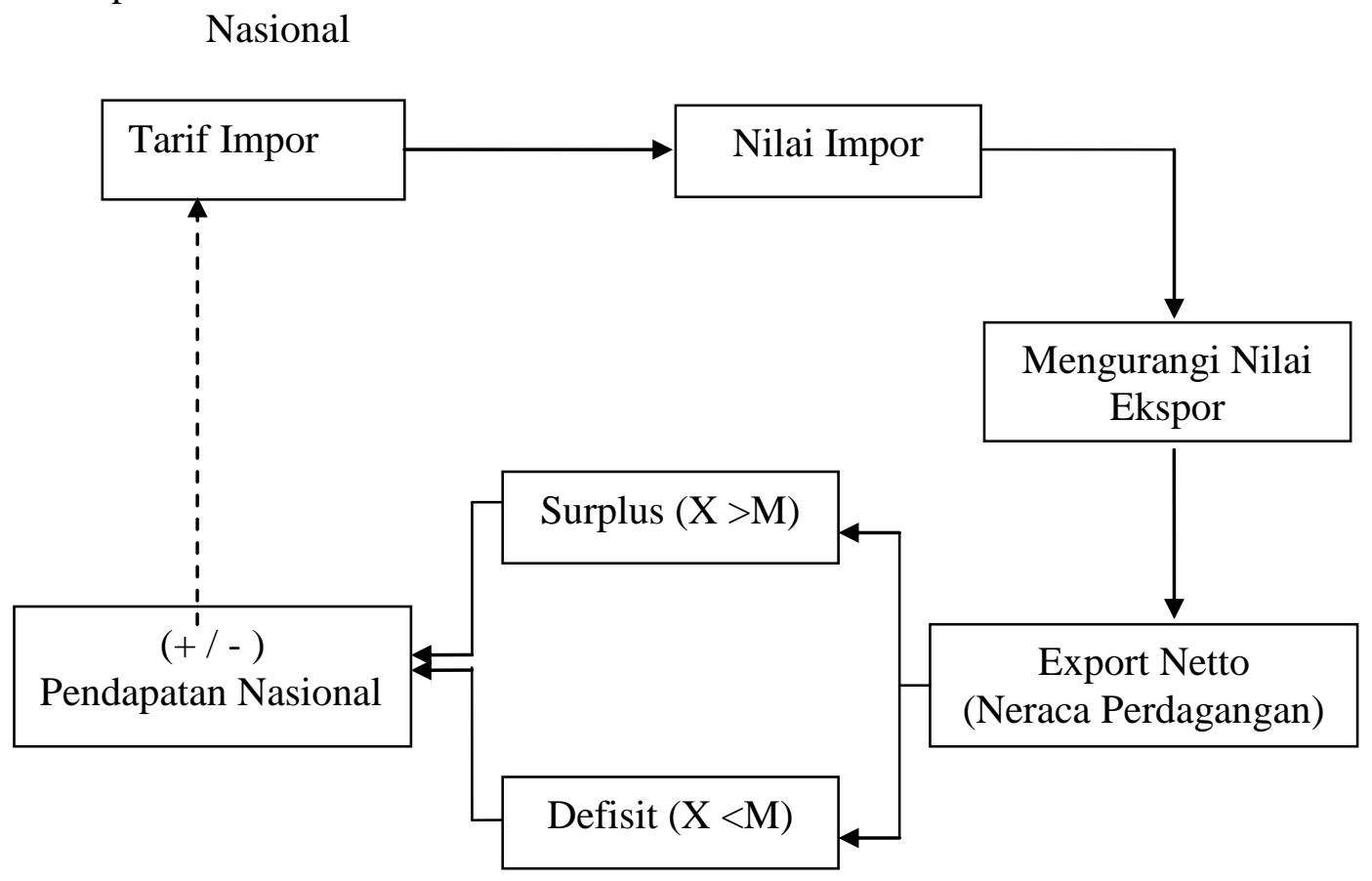


Sesuai dengan uraian tersebut di atas dapat ditarik hipotesis "Bahwa tarif berpengaruh positif dan signifikan terhadap perkembangan neraca perdagangan" METODE PENELITIAN

Dalam penelitian ini, objek yang dibahas untuk diteliti adalah mencangkup komoditi barang impor untuk non migas (pertanian dan manufaktur) di Indonesia yang tertera pada Surat Pemberitahuan Impor Barang (PIB) yang dikeluarkan oleh Ditjen Bea dan Cukai pada tahun 1995 - 2005.

Jenis penelitian ini adalah deskriptif kuantitatif. Data yang akan digunakan dalam skala numerik yang diambil dari data sekunder. Datanya berupa data berkala (data time series) selama 11 tahun dari tahun 1995 - 2005 (penerapannya per triwulan untuk neraca perdagangan, pendapatan dalam negeri, harga keseluruhan, harga untuk barang ekspor dan impor, kurs tukar, dan tariff). Data tersebut diperoleh dari beberapa instansi yang terkait yaitu Bank Indonesia (SEKI edisi tiga bulanan tahun 1995-2005), Departemen Keuangan (Peraturan Menteri Keuangan Nomor 591/ PMK.010 / 2004), Badan Pusat Statistik (Statistik Indonesia tahun 1995-2005) Ditjen Bea dan Cukai (Dokumen Pemberitahuan Impor Barang tanun 1995-2005).

Alat analisis yang digunakan adalah pendekatan model dinamis. Koefisien yang terdapat dalam model ditaksir dengan menggunakan metode OLS (Ordinary Least Square). Model yang digunakan dalam penelitian ini erat kaitannya dengan bentuk data time series. Dalam data time series terdapat anggapan apabila variasi variabel endogen periode yang berlaku tidak saja ditentukan oleh variabel eksogen menurut periode yang sama, tetapi juga ditentukan oleh variabel eksogen sebelumnya. Sehingga sudah sepatutnya apabila menganalisis sebuah permasalahan yang berkenaan dengan data time series digunakan model dinamis. Disamping alasan-alasan diatas masih terdapat beberapa alasan kuat lainnya mengapa penggunaan model dinamis menjadi hal yang begitu penting dalam penelitian ekonomi dengan menggunakan data time series, yaitu alasan psikologis, alasan kelambanan dan alasan teknologi (Gujarati, 1995: 589-590). 
Dari model perekonomian terbuka (persamaan 1), maka akan diketahui bahwa expor netto merupakan salah satu komponen yang dapat menambah pendapatan suatu negara. Expor netto itu sendiri adalah hasil dari ekspor dikurangi impor (X-M). Sehingga untuk mengetahui pengaruh yang ditimbulkan oleh tarif terhadap perkembangan neraca perdagangan maka sesuai kaidah penggunaan metode OLS ditentukan model regresi sebagai berikut:

$$
\Delta \mathrm{EN}=\beta_{0}+\beta_{1} \mathrm{t}_{\mathrm{m}}+
$$

$e$

$\triangle \mathrm{EN}$ merupakan perubahan neraca perdagangan di Indonesia dari tahun 1995-2005, dan $t_{m}$ merupakan besarnya tariff impor. Dari model tersebut diketahui bagaimana pengaruh yang ditimbulkan dari nilai tarif impor terhadap perkembangan neraca perdagangan. Tetapi, karena karena dalam penelitian ini meneliti tentang tarif impor yang dikenakan terhadap nilai impor yang terdapat dalam neraca perdagangan, maka sebelum model diatas digunakan akan digunakan terlebih dahulu model yang berhubungan langsung dengan tarif agar dapat dijadikan perbandingan. Yaitu yang pertama, sebelum diteliti mengenai bagaimana pengaruh tariff impor terhadap neraca perdagangan maka akan dibahas terlebih dahulu mengenai bagaimana pengaruh tariff impor itu sendiri terhadap nilai impor dengan menggunakan model regresi sebagai berikut:

$$
M=\beta o+\beta_{1} Y+\beta_{2} P m+\beta_{3} P+\beta_{4} t_{m}+\beta_{5} e r+
$$

$$
e
$$

model diatas merupakan model untuk mengetahui pengaruh tarif terhadap nilai impor. Ditentukannya model seperti diatas karena:

$$
M=f\left(Y, P m, P, t_{m},\right.
$$

er)

munculnya variabel independen lain dalam model diatas selain tarif impor dikarenakan nilai impor (M) adalah fungsi dari pendapatan pemerintah (Y), harga barang ekspor (Px), indeks harga keseluruhan (P), dan nilai kurs tukar (er).

Karena dalam pembahasan dari penelitian ini menggunakan analisis regresi dengan menggunakan data time series, maka perlu dilakukan pencegahan 
untuk menghindari hasil regresi yang lancung. Model koreksi kesalahan (error correction model) menjadi isu yang sering dibicarakan sejak tahun 1960 untuk menganalisis model time series. Model kereksi kesalahan diyakini dapat menguji spesifikasi model yang digunakan dalam menganalisis fenomena ekonomi dengan data time series valid dan tidak, yaitu berdasarkan atas nilai error correction termnya. Disamping itu model koreksi kesalahan dengan pendekatan kointegrasi dapat menghindarkan model yang digunakan dari adanya regresi lancung yang dapat mengacaukan analisis dengan memanfaatkan model time series (Insukindro dalam Wibisono, 1999: 54-55).

Salah satu ciri-ciri terjadinya regresi lancung adalah nilai $\mathrm{R}^{2}$ yang tinggi disertai dengan nilai DW yang rendah. Akibat dari adanya regresi lancung adalah terdapatnya koefisien regresi penaksir yang tidak efisien, peramalan dengan menggunakan regresi tersebut akan meleset dan uji baku untuk koefisien regresi tersebut tidak sahih (Insukindro dalam Wibisono, 1991: 76-77).

Untuk menghindari adanya munculnya regresi lancung (spurious) dan melihat hubungan kausalitas jangka panjang dari variabel-variabel ekonomi yang sedang diamati digunakan model ECM (Error Correction Model). Untuk menjelaskan hubungan antara perkembangan neraca perdagangan $(\Delta \mathrm{EN})$ atau (EN) dan tarif impor $\left(\mathrm{t}_{\mathrm{m}}\right)$ dari model 11, maka dilakukan estimasi dengan model sebagai berikut:

$\Delta \mathrm{EN}=\beta_{0}+\beta_{1} \mathrm{t}_{\mathrm{m}}+\Delta \beta_{2} \mathrm{t}_{\mathrm{m}-1}+\beta_{3} \mathrm{ECT}+e$.

Dimana ECT $=\Delta \beta_{2} \mathrm{t}_{\mathrm{m}-1-1}-\Delta \mathrm{EN}_{\mathrm{t}-1}$

$(\mathrm{t}-1)=$ kelambanan waktu satu tahun sebelumnya, dan ECT adalah error correction term dari persamaan yang diuji. Tariff impor $\left(\mathrm{t}_{\mathrm{m}}\right)$ disini yang digunakan adalah tariff komoditi non migas untuk pertanian dan manufaktur. Sedangkan neraca perdagangan (EN) yang akan diteliti adalah perkembangannya dari tahun ke tahun $(\Delta)$. Model diatas diharapkan dapat diterapkan untuk melihat pengaruh tariff impor terhadap neraca perdagangan dalam jangka panjang maupun dalam jangka pendek. 
Sedangkan untuk melihat kelayakan model yang digunakan untuk persamaan 12, yaitu melihat pengaruh fungsi impor (termasuk tarif impor )terhadap nilai impor adalah:

$\mathrm{M}=\beta \mathrm{o}+\beta_{1} Y+\beta_{2} P_{M}+\beta_{3} P+\beta_{4} t_{M}+\beta_{5} e r+\beta_{6} Y_{t-1}+\beta_{7} P_{M t-1}+\beta_{8} P_{t-1}+\beta_{9} t_{M t-1}+\beta_{10} e r_{t-1}+\beta_{11} \mathrm{ECT}$

$+e \ldots \ldots . . .(16)$

Dimana:

$\mathrm{ECT}_{t-1}=\Delta \beta Y_{t-1}+\Delta \beta P_{M t-1}+\Delta \beta P_{t-1}+\Delta \beta t_{M t-1}+\Delta \beta e r-$

M.

Tahapan pengujian dari model ECM yang dikenakan pada model 14 dan 16, selain untuk menghindari hasil regresi yang lancung adalah dapat digunakan untuk menganalisis hubungan jangka panjang dan hubungan jangka pendek dari variabel-variabel ekonomi yang digunakan. Selain itu, model koreksi kesalahan terdapat keseimbangan yang tetap dalam jangka panjang antara variabel-variabel ekonomi. Bila dalam jangka pendek terdapat ketidak seimbangan dalam satu periode, maka model koreksi kesalahan akan mengoreksinya pada periode berikutnya (Aliman,2001).

\section{HASIL PENELITIAN}

\section{Estimasi Variabel dengan Model ECM}

Hasil dari estimasi model ECM untuk mengetahui apakah variablevariabel ekonomi yang dipakai dalam penelitian ini dapat digunakan atau tidak, dari model 14. dapat diketahui pada table 2 berikut:

Tabel 2.Estimasi Dengan ECM

Untuk Variabel Tarif Impor Terhadap Perkembangan Neraca Perdagangan

Dependent Variable: $\triangle \mathrm{EN}$

\begin{tabular}{lcllr}
\hline \multicolumn{1}{c}{ Variable } & Coefficient & Std. Error & t-Statistic & Prob. \\
\hline \hline \multicolumn{1}{c}{ ECT } & 0.186133 & 0.127293 & 9.318103 & 0.0000 \\
\hline \hline R-squared & 0.694778 & F-statistic & & 29.59195 \\
Adjusted R-squared & 0.671299 & Prob(F-statistic) & 0.000000 \\
\hline \multicolumn{2}{l}{ Sumber: Data Sekunder, diolah Kembali. } &
\end{tabular}

diketahui bahwa koefisien $\beta_{3}$ atau nilai error correction term-nya signifikan dan mempunyai tanda yang positif. Dengan demikian dapat dikatakan bahwa model 
ECM sukses dan dapat digunakan dalam mengestimasi pengaruh tarif impor terhadap perkembangan neraca perdagangan. Kemudian, dengan signifikannya nilai koefisien $\beta_{3}$ berarti bahwa spesifikasi model persamaan regresi yang digunakan yaitu; $\Delta \mathrm{EN}=\beta_{0}+\beta_{1} \mathrm{t}_{\mathrm{m}}+e$ adalah valid.

Kemudian untuk mengetahui pula apakah varabel-variabel yang digunakan pada persamaan 12 dapat digunakan atau tidak, maka dilakukan pengujian dengan menggunakan model ECM pada persamaan 16. dengan hasil sebagai berikut:

Tabel 4.Estimasi Dengan ECM

Untuk Variabel Fungsi Impor Terhadap Perkembangan Neraca Perdagangan

\begin{tabular}{lrlrr}
\hline \multicolumn{1}{c}{ Variable } & Coefficient & \multicolumn{1}{c}{ Std. Error } & t-Statistic & Prob. \\
\hline \hline ECT & 0.257408 & 0.032632 & 6.245572 & 0.0254 \\
\hline \hline R-squared & 0.777506 & F-statistic & & 7.361366 \\
Adjusted R-squared & 0.769925 & Prob(F-statistic) & 0.000000 \\
\hline Sumber: Data Sekunder, diolah kembali. & & &
\end{tabular}

Koefisien $\beta_{3}$ positif dan signifikan. Dengan demikian dapat dikatakan bahwa model ECM sukses dan dapat digunakan dalam mengestimasi pengaruh fungsi impor terhadap nilai impor.

\section{Hasil Uji Hipotesis}

Hasil pengujian model regresi untuk jangka panjang $M=-2,4078+$ $0,1769 Y-2,3963 P-1,6373 P m+0,0524 T m+3,1675 e r$. Menunjukkan bahwa hubungan tarif impor terhadap barang impor adalah positif pada level of signifikan $5 \%$ dan $\mathrm{R}^{2}=83 \%$. Sedangkan uji $\mathrm{F}$ yang dilakukan menyatakan bahwa model diatas memiliki nilai $\mathrm{F}_{\text {statistik }}$ yang lebih kecil dibandingkan dengan $\mathrm{F}_{\text {tabel }}$ yaitu 29,54 .

Pengaruh tarif impor terhadap perkembangan neraca perdagangan $\Delta \mathrm{EN}=$

$$
5,2911+0,1315 \mathrm{t}_{\mathrm{m}}
$$

Diperoleh koefisien regresi variabel nilai tarif impor $\left(\mathrm{T}_{M}\right)$ sebesar 0.1315 ; berarti ada pengaruh positif antara nilai tarif impor terhadap perkembangan neraca perdagangan sebesar 13,2\%. Jadi, apabila nilai tarif impor akan turun sebesar \$ 1 juta, maka perkembangan neraca perdagangan juga akan turun sebesar $\$ 13,2$ juta. Demikian juga sebaliknya, apabila tingkat tarif impor naik sebesar \$ 1 juta, 
maka perkembangan neraca perdagangan akan naik sebesar $\$ 13,2$ juta. Nilai $R^{2}=$ $83 \%$ yang berarti kemampuan variabel bebas dalam menjelaskan variabel terikat sebesar $83 \%$. Sedangkan uji F yang dilakukan menyatakan bahwa $\mathrm{F}_{\text {statistik }}$ lebih besar daripada $\mathrm{F}_{\text {tabel }}$ senilai 29,54.

Pengujian terhadap masalah autokorelasi dengan menggunakan uji LM yang diperkenalkan oleh Breusch dan Godfrey. Diketahui bahwa nilai $\chi_{\text {-hitung }}^{2}$

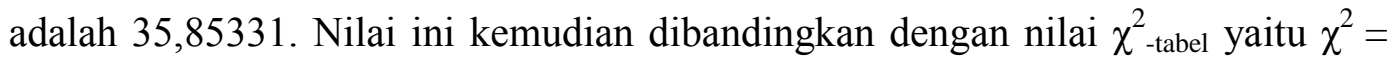
41,9915. Pedoman yang digunakan adalah apabila $\chi^{2}$-hitung uji $\mathrm{LM}>$ dibandingkan dengan nilai $\chi_{\text {-tabel }}^{2}$, maka hipotesis yang menyatakan bahwa model empirik bebas dari masalah autokorelasi adalah diterima. Oleh karena $\chi_{\text {-tabel }}^{2} 35,85331>41,9915$, maka dapat disimpulkan bahwa model yang terdapat pada penelitian ini lolos dari masalah autokorelasi.

Kemudian dilakukan pula pengujian terhadap masalah heteroskedastisitas dengan menggunakan uji White yang dikembangakan oleh Engle. Untuk hasil

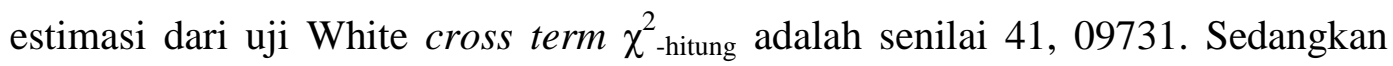
nilai dari $\chi_{\text {-tabel }}^{2}$ adalah sebesar 52,2265. oleh karena $\chi_{\text {-hitung }}^{2} \chi_{\text {-tabel }}^{2}$, maka dapat disimpulkan bahwa hipotesis yang menyatakan bahwa model yang diteliti terbebas dari masalah heteroscedastisitas adalah diterima.

\section{Tarif Impor Dan Perkembangan Neraca Perdagangan Indonesia.}

Pengaruh yang ditimbulkan dari besarnya nilai tarif impor terhadap perkembangan neraca perdagangan dapat diketahui dari pengaruh masing-masing tarif terhadap nilai ekspor maupun impor. Tarif impor berpengaruh positif terhadap perkembangan neraca perdagangan. Berarti apabila pemerintah memberlakukan kenaikan tarif maka neraca perdagangan akan mengalami kenaikan, demikian juga sebaliknya. Namun, dari data perkembangan neraca perdagangan yang ada menunjukkan bahwa perkembangan neraca perdagangan tidak selalu mengalami kenaikan seperti yang diharapkan. Walaupun tarif impor dapat berdampak positif terhadap perkembangan neraca perdagangan tetapi pemerintah tidak bebas untuk menaikkan tarif impor untuk memproteksi barang 
dalam negeri karena dengan adanya perdagangan global maka banyak sekali aturan-aturan tertentu yang tidak dapat dilanggar oleh suatu negara untuk menaikkan tarif.

Selain itu, Indonesia sebagai negara berkembang juga membutuhkan banyak barang impor yang tidak bisa diproduksi dalam negeri. Sehingga, pemerintah memberikan kebijakan tarif impor untuk membatasi impor suatu barang tapi disisi lain pemerintah memberikan tarif impor terhadap suatu barang tetapi tetap membelanjakan barang tersebut dengan royal/tanpa batasan.

Untuk lebih memperjelas kondisi demikian, maka dapat dilihat pada model yang memperlihatkan pengaruh tarif impor. Dari hasil regresi diketahui bahwa seluruh variabel bebas $(Y, P, P m, T m, E r)$ setelah melalui pengujian dengan model dinamis, dapat mempengaruhi besarnya nilai impor. Yang mendapat perhatian khusus disini adalah besarnya nilai tarif impor yang pengaruhnya sebesar 0,0524, bertentangan dengan pendapat yang telah dikemukaan oleh Kindleberger dan Lindert (1983), bahwa "ada beberapa alasan pemerintah yang memilih menggunakan tarif untuk membatasi impor. Yaitu untuk memastikan agar peningkatan pengeluaran impor yang lebih lanjut bisa direm apabila persaingan luar negeri mulai meningkat."

Secara mudah dapat diartikan bahwa; tarif digunakan untuk menghambat masukknya impor dalam negeri. Berarti harapannya, melalui kenaikan tarif impor maka nilai impor akan menurun demikian juga sebaliknya jika tarif turun maka akan menaikkan nilai impor. Tetapi yang terjadi, dari hasil penelitian yang dilakukan, adalah tidak demikian. Jadi tarif tidak berpengaruh negatif tetapi berpengaruf positif.

Karena hasil yang dicapai tidak sesuai teori yang ada, berarti di Indonesia pemerintah senantiasa berusaha untuk menghambat lajunya impor yang masuk ke dalam negeri melalui tarif. Namun, kebutuhan akan barang-barang impor masih sangat dominan. Hal itu diketahui meningkatnya trend nilai impor dari tahun ke tahun. Artinya, walaupun keadaan neraca perdagangan senantiasa dalam keadaan surplus tetapi nilai impor juga semakin meningkat. 
Kondisi demikian dapat dipahami seperti yang dikemukanan BPS (1995). Nilai impor bahan baku dan penolong sejak tahun 1995 terus meningkat. Pada tahun 1996 nilai impor bahan baku dan penolong hanya mencapai 8.363,9 juta US dolar, kemudian terus meningkat pada tahun-tahun berikutnya. Kenaikan tersebut terjadi pada bahan baku untuk industri, suku cadang dan perlengkapannya. Pada tahun 1999 nilai impor bahan baku dan penolong sudah mencapai 23.133,6 juta US dolar. Nilai impor golongan barang ini pada tahun 2000 mencapai 29.586,6 juta US dolar atau naik 27,9 persen dibanding tahun sebelumnya.

Nilai impor barang-barang modal menunjukkan pola yang sama dengan bahan baku dan penolong, yaitu cenderung naik terus sampai dengan tahun 1996. pada tahun 1998 nilai impor barang naik menjadi 8.691,7 juta dolar untuk barang modal.

Negara- negara utama asal impor pada tahun 1995 masih didominasi oleh Jepang, Amerika Serikat, MEE dan ASEAN. Nilai impor Indonesia dari negaranegara ASEAN mencapai 2.927,7 juta US dolar, dan sebesar 64,1 persennya berasal dari Singapura. Sedangkan nilai impor Indonesia dari MEE sebesar $5.827,9$ juta US dolar dengan 42,4 persennya merupakan barang impor dari Jerman.

Jadi sesuai seperti yang dikemukakan oleh BPS diatas. Tidak mengherankan apabila pengaruh tarif terhadap nilai impor berbanding positif. Kondisi demikian dapat dipahami bahwa pemerintah senantiasa membatasi impor yang masuk untuk melindungi produksi dalam negeri, tetapi tidak untuk seluruh produksi. Tarif tersebut difokuskan untuk produk-produk padat karya dan produkproduk pertanian. Tetapi untuk barang-barang lainnya seperti barang modal, bahan baku dan penolong pemerintah senantiasa menambah impor yang masuk walaupun telah dikenakan tarif. Barang modal, bahan baku dan penolong tersebut paling banyak adalah untuk industri. 


\section{KESIMPULAN}

Penggunaan pendekatan model aplikasi dinamik dalam menentukan pengaruh tarif impor terhadap perkembangan neraca perdagangan di Indonesia dinyatakan valid. Hal ini dilihat dari nilai koefisien variabel yang signifikan dan positif.

Tampaknya terdapat perbedaan pengaruh tingkat besarnya tarif impor dalam jangka panjang dan dalam jangka pendek terhadap perkembangan neraca perdagangan. Walaupun dalam jangka pendek nilai tarif tidak berpengaruh secara signifikan terhadap perkembangan neraca perdagangan. Namun nilai tarif impor memiliki tanda yang positif. Sehingga pengaruhnya untuk jangka panjang tarif impor akan memberikan dampak yang signifikan terhadap pekembangan neraca perdagangan. Karena itu penerapan tariff impor dipandang masih memiliki nilai strategis terutama bagi upaya peningkatan daya saing produk ekspor andalan Indonesia.

Sebagai komponen aktivitas ekonomi yang memiliki kontribusi strategis bagi pertumbuhan sektor produksi di Indonesia, maka untuk mendapatkan manfaat yang lebih berarti dalam jangka panjang, kebijakan pengenaan tarif impor perlu didesain sejalan dengan strategi pengembangan komoditi ekspor yang dijadikan andalan di pasar internasional. Misalnya, untuk tarif impor komoditi manufaktur non pertanian terutama bahan baku bagi industri dalam negeri tariff impor sebaiknya didiversifikasi sesuai skala prioritas dan prospek industri yang hendak dikembangkan di masa datang.

\section{DAFTAR PUSTAKA}

Aliman. 2001. Pelatihan Ekonometrika Analisis Runtun Waktu: Program Eviews3. Modul Panduan. Fakultas Ekonomi. Universitas Muhammadiyah Malang.

Aliman \& Damrin, Ade.2000. Indonesia Adalah Pertumbuhan Ekonomi Mendorong Ekspor. Jurnal Manajemen daya Saing. Vol. 1 No. 2. Hal. $115-126$

Astiyah, Siti. dkk. 2005. Dampak Liberalisasi Perdagangan terhadap Perilaku Pembentukan Harga Produk Industri melalui Structure-Conduct Performe 
Model. Buletin Ekonomi Moneter dan Perbankan, Maret 2005. Direktorat Riset dan Kebijakan Moneter Bank Indonesia.

Badan Pusat Statistik. Statistik Perekonomian Indonesia 1995-2005.

Bank Indonesia. Statistik Ekonomi dan Perekonomian Indonesia per tiga bulanan Tahun 1995.1 - 2005.4.

Basri, Faisal. 1995. Perekonomian Indonesia Menjelang Abad 21. Erlangga. Jakarta.

Basuki, Agus Tri. 2000. Analisis Tingkat Tarif Proteksi Efektif Di Sektor Industri Tahun 1995. Jurnal Ekonomi dan Studi Pembangunan Vol. 1, No. 1/ April 2000. Fakultas Ekonomi, Universitas Muhammadiyah Yogyakarta.

Bhagwati, Jagdish. 1992. Proteksionisme. Edisi Bahasa Indoensia. Diterjemahkan Tom Gunadi. Angkasa. Bandung.

Gujarati, Damodar. 1978. Ekonometrika Dasar. Penerbit Erlangga. Jakarta.

Hady, Hamdy. 2004. Ekonomi Internasional : Teori dan Kebijakan Keuangan Internasional. Ghalia Indonesia. Jakarta.

Kariyasa, Ketut. 2003. Dampak Tarif Impor Dan Kinerja Kebijakan Harga Dasar Serta Implikasinya Terhadap Daya Saing Beras Indonesia Di Pasar Dunia. Jurnal Analisis Kebijakan Pertanian, Vol. 1, No. 4/ Desember 2003. Pusat Penelitian dan Pengembangan Sosial Ekonomi Pertanian Bogor.

Kartadjoemena,H.S. Gatt Dan WTO, Sistem, Forum Dan Lembaga Internasional Di Bidang Perdagangan. UIP, Jakarta

Krugman and Obstfeld. 1991. Ekonomi Internasional : Teori dan Kebijakan. Penerbit CV. Rajawali. Jakarta.

Lindert and Kindleberger. 1983. Ekonomi Internasional. Edisi Ketujuh. Penerbit Erlangga. Jakarta.

Mankiw,N. Gregory. 2003. Teori Makroekonomi. Edisi 5. Penerbit Erlangga. Jakarta.

Republik Indonesia, Peraturan Menteri Keuangan. No. 591/Kmk.01/2004. Tentang Program Harmonisasi Tarif Bea Masuk Tahun 2005-2010 Untuk Produk-Produk Pertanian, Perikanan, Pertambangan, Farmasi, Keramik, dan Besi Baja.

Salvatore, Dominick. 2000. Ekonomi Internasional. Jilid 2. Penerbit Erlangga. Jakarta.

Tambunan, Tulus T.H. 2004. Globalisasi dan Perdagangan Internasional. Ghalia Indonesia. Jakarta.

Wibisono, Rachmad. 2003. Identifikasi Peran Ekspor, Investasi Dan Liberalisasi Keuangan Dalam Peningkatan Pertumbuhan Ekonomi Indonesia: Studi Setelah Tahun 1983 (Aplikasi Model Dinamik). Jurnal Ekonomi 
Pembangunan. Vol.1, No.1. Ilmu Ekonomi dan Studi Pembangunan. Fakultas Ekonomi. UMM. 